\title{
Invasive bacteria isolates from children with cerebral shunt and pattern of antimicrobial drug susceptibility in an Iranian referral pediatrics center
}

Dear Editor,

Shunt infection is the most important complication of cerebral shunt implantation, especially in the pediatric age group. ${ }^{1,2}$ Prompt diagnosis of shunt infection and appropriate antibiotic therapy are essential to avoid further complications. In addition, correct knowledge of local antimicrobial susceptibility profile is needed, as effectiveness of treatment is limited by antibiotic resistant bacterial strains, ${ }^{3,4}$ especially in regions with irregular use of antibiotics in the general population.

This study was conducted in the main referral center in Tehran, Iran from April 2008 to March 2009 to identify the etiologies of shunt infections and antibiotic resistance. Patients with cerebral shunt who had been admitted to the Childrens Medical Center, Pediatrics Center of Excellence in Iran, were enrolled in this study. Cerebrospinal fluid (CSF) specimens were processed immediately by microbiological standard methods, including Gram staining and bacterial culture. Susceptibility to antibiotics was determined by diffusion method, according to CLSI standards.
Fifty-seven cases with cerebral shunt and positive CSF culture were included in this study. The Gram staining was positive for 32 out of 57 subjects (56.1\%). Culture identification revealed coagulase-negative Staphylococcus in 17 subjects (29.8\%) and Staphylococcus aureus in 15 subjects (26.3\%) as the most common Grampositive bacteria. Pseudomonas spp. was the most common Gram-negative organism, which was detected in 14 patients (24.6\%), followed by Enterobacter aerogenes (6 cases) and Klebsiella pneumoniae (5 cases). Antibiotic susceptibility tests revealed that vancomycin had the best effect on Gram-positive organisms in comparison with other antibiotics (Table 1). Pseudomonas spp., E. aerogenes, and K. pneumoniae were more susceptible to gentamycin, trimethoprim, and meropenem, respectively (Table 1).

This study showed that coagulase-negative Staphylococcus, S. aureus, and Pseudomonas spp. were the most common organisms responsible for shunt infections. In the present study, antibiotic susceptibility tests for coagulasenegative Staphylococcus showed that almost all (except two) were susceptible to vancomycin.

Table 1. Antimicrobial susceptibility profiles of selected Gram-positive and Gram-negative pathogens causing shunt infections in Iranian children

\begin{tabular}{lccccc}
\hline & $\begin{array}{c}\text { Coagulase } \\
\text { negative } \\
\text { Staphylococcus }\end{array}$ & $\begin{array}{c}\text { Staphylococcus } \\
\text { aureus }\end{array}$ & $\begin{array}{c}\text { Pseudomonas } \\
\text { spp. }\end{array}$ & $\begin{array}{c}\text { Enterobacter } \\
\text { aerogenes }\end{array}$ & $\begin{array}{c}\text { Klebsiella } \\
\text { pneumo- } \\
\text { niae }\end{array}$ \\
Antibiotics & $\mathbf{n}=\mathbf{1 7}$ & $\mathbf{n = 1 5}$ & $\mathbf{n = 1 4}$ & $\mathbf{n = 6}$ & $\mathbf{n}=\mathbf{5}$ \\
\hline Vancomycin & $88.2 \%$ & $40 \%$ & - & - & - \\
\hline Amikacin & $52.9 \%$ & $6.7 \%$ & - & - & - \\
\hline Gentamycin & $41.2 \%$ & $13.3 \%$ & $92.9 \%$ & $33.3 \%$ & - \\
\hline Cephalothin & $41.2 \%$ & $6.7 \%$ & - & - & - \\
\hline Meropenem & - & - & $14.3 \%$ & $66.6 \%$ & $100 \%$ \\
\hline Trimethoprim & - & - & $35.7 \%$ & $83.3 \%$ & $20 \%$ \\
\hline Imipenem & - & - & - & - & $80 \%$
\end{tabular}

Submitted on: 11/16/2010 Approved on: 03/30/2011

Correspondence to: Mohammad Taghi HaghiAshtiani

Children's Medical Center Hospital,

Dr. Qarib St, Keshavarz

Blvd, Tehran, Iran ashtiani20@yahoo.com mmpour@tums.ac.ir

We declare no conflict of interest. 
This antibiotic was also effective in $40 \%$ of cases with S. aureus. Pseudomonas spp., E. aerogenes, and K. pneumoniae were more susceptible to gentamycin, trimethoprim, and meropenem, respectively. Thus, a combination of vancomycin, gentamycin and/or meropenem could be considered for empirical therapy of shunt infections in our hospital, when there is no clue for the type of agent before the results of CSF culture is being processed. It should be noted that application of this antibiotic therapy strategy to other settings is limited as this was a hospital-based study. Further long-term prospective studies involving different hospitals of the country should be performed to provide better estimation of microorganisms and their bacterial susceptibility profile, which could hopefully lead to decreasing morbidity and mortality rate of shunt infections.

\section{REFERENCES}

1. Knoop M, Schütze M, Piek J et al. Antibiotic prophylaxis in cerebrospinal fluid shunting: reassessment of Cefotiam penetration into human CSF. Zentralbl Neurochir 2007; 68:14-8.

2. Ratilal B, Costa J, Sampaio C. Antibiotic prophylaxis for surgical introduction of intracranial ventricular shunts: a systematic review. J Neurosurg Pediatr 2008; 1:48-56.

3. Jacobs MR, Felmingham D, Appelbaum PC et al. Alexander Project Group. The Alexander Project 1998-2000: susceptibility of pathogens isolated from community-acquired respiratory tract infection to commonly used antimicrobial agents. J Antimicrob Chemother 2003; 52:229-46.

4. Quagliarello VJ, Scheld WM. Treatment of bacterial meningitis. N Engl J Med 1997; 336:708-16. 